J. Dairy Sci. 95:6905-6917

http://dx.doi.org/10.3168/jds.2012-5675

(C) American Dairy Science Association ${ }^{\circledR}, 2012$.

\title{
Distinct composition of bovine milk from Jersey and Holstein-Friesian cows with good, poor, or noncoagulation properties as reflected in protein genetic variants and isoforms
}

\author{
H. B. Jensen, ${ }^{\star 1}$ N. A. Poulsen, ${ }^{\star}$ K. K. Andersen, ${ }^{*}$ M. Hammershøj, ${ }^{\star}$ H. D. Poulsen, $†$ and L. B. Larsen ${ }^{\star}$ \\ *Department of Food Science, and \\ †Department of Animal Science, Aarhus University, 8830 Tjele, Denmark
}

\begin{abstract}
The objective of this study was to examine variation in overall milk, protein, and mineral composition of bovine milk in relation to rennet-induced coagulation, with the aim of elucidating the underlying causes of milk with impaired coagulation abilities. On the basis of an initial screening of 892 milk samples from 42 herds with Danish Jersey and Holstein-Friesian cows, a subset of 102 samples was selected to represent milk with good, poor, or noncoagulating properties (i.e., samples that within each breed represented the most extremes in regard to coagulation properties). Milk with good coagulation characteristics was defined as milk forming a strong coagulum based on oscillatory rheology, as indicated by high values for maximum coagulum strength $\left(\mathrm{G}_{\max }^{\prime}\right)$ and curd firming rate (CFR) and a short rennet coagulation time. Poorly coagulating milk formed a weak coagulum, with a low $\mathrm{G}_{\text {max }}^{\prime}$ and CFR and a long rennet coagulation time. Noncoagulating milk was defined as milk that failed to form a coagulum, having $\mathrm{G}_{\text {max }}^{\prime}$ and CFR values of zero at measurements taken within $1 \mathrm{~h}$ after addition of rennet. For both breeds, a lower content of total protein, total casein $(\mathrm{CN})$ and $\kappa-\mathrm{CN}$, and lower levels of minerals $(\mathrm{Ca}, \mathrm{P}, \mathrm{Mg}$ ) were identified in poorly coagulating and noncoagulating milk in comparison with milk with good coagulation properties. Liquid chromatography/electrospray ionization-mass spectrometry revealed the presence of a great variety of genetic variants of the major milk proteins, namely, $\alpha_{S_{1}}-\mathrm{CN}$ (variants $\mathrm{B}$ and $\mathrm{C}$ ), $\alpha_{\mathrm{S} 2}-\mathrm{CN}$ (A), $\beta-\mathrm{CN}\left(\mathrm{A}^{1}, \mathrm{~A}^{2}, \mathrm{~B}, \mathrm{I}\right.$, and $\left.\mathrm{F}\right), \kappa-\mathrm{CN}(\mathrm{A}, \mathrm{B}$, and $\mathrm{E})$, $\alpha$-lactalbumin (B), and $\beta$-lactoglobulin (A, B, and C). In poorly coagulating and noncoagulating milk samples of both breeds, the predominant composite genotype of $\alpha_{\mathrm{S1}^{-}}, \beta-$, and $\kappa^{-} \mathrm{CN}$ was $\mathrm{BB}-\mathrm{A}^{2} \mathrm{~A}^{2}-\mathrm{AA}$, which confirmed a genetic contribution to impaired milk coagulation. Interestingly, subtle variations in posttranslational modi-
\end{abstract}

Received May 1, 2012.

Accepted August 25, 2012.

${ }^{1}$ Corresponding author: hanne.bakjensen@agrsci.dk fication of $\mathrm{CN}$ were observed between the coagulation classes in both breeds. Poorly coagulating and noncoagulating milk contained a lower fraction of the least phosphorylated $\alpha_{\mathrm{S}_{1}-} \mathrm{CN}$ form, $\alpha_{\mathrm{S}_{1}} \mathrm{CN} 8 \mathrm{P}$, relative to total $\alpha_{\mathrm{S} 1}-\mathrm{CN}$, along with a lower fraction of glycosylated $\kappa-\mathrm{CN}$ relative to total $\kappa-\mathrm{CN}$. Thus, apparent variation was observed in the milk and protein composition, in the genetic makeup of the major milk proteins, and in the posttranslational modification level of $\mathrm{CN}$ between milk samples with either good or impaired coagulation ability, whereas the composition of poorly coagulating and noncoagulating milk was similar.

Key words: rennet-induced milk coagulation, posttranslational modification, liquid chromatography, mass spectrometry

\section{INTRODUCTION}

The protein fraction of bovine milk consists, in large part $(\approx 90 \%)$, of 6 major proteins, namely, $4 \mathrm{CN}\left(\alpha_{\mathrm{S1}^{-}}\right.$, $\alpha_{\mathrm{S}^{-}}, \beta-$, and $\left.\kappa^{-}\right)$in the mutual ratio of 4:1:4:1 (by wt), together with 2 whey proteins, $\beta$-LG and $\alpha$-LA, in the mutual ratio of 3:1 (wt/wt; Walstra, 1999; Farrell et al., 2004; Fox, 2009). The majority of the $\mathrm{CN}$ is incorporated into large colloidal aggregates known as CN micelles (Dalgleish, 1992; Walstra, 1999). Despite the CN micelle structure not being fully elucidated, consensus persists that the CN micelle is a network of protein molecules stabilized by a combination of attractive hydrophobic interactions and repulsive electrostatic forces between $\mathrm{CN}$ molecules, along with Ca-mediated interactions between phosphoserine (pSer) clusters found on the Ca-sensitive $\mathrm{CN}\left(\alpha_{\mathrm{S1}^{-}}, \alpha_{\mathrm{S2}^{-}}\right.$, and $\left.\beta-\mathrm{CN}\right)$ and colloidal calcium phosphate in the core of the CN micelles (Holt, 1992; Horne, 1998; Walstra, 1999). Furthermore, $\kappa-\mathrm{CN}$ is located at the surface of the $\mathrm{CN}$ micelles, extending as "hairs" as far as $12 \mathrm{~nm}$ from the micelle surface (Holt, 1992), giving the micelles a net negative charge and sterically stabilizing the micelles against aggregation (Walstra, 1999). The CN micelles are the basic building blocks of the gel formed during rennet-induced coagulation of milk in the processing of 
cheese (Lucey, 2009). Milk with good coagulation ability is a preferred raw material for the dairy industry; therefore, it is of interest to understand the underlying causes of milk with impaired coagulation ability, which is a common problem in several studied dairy breeds (Malossini et al., 1996; Ikonen et al., 1999, 2004; Tyrisevä et al., 2003, 2004; Hallén et al., 2010; Frederiksen et al., 2011b).

Enzymatic coagulation of milk is a 2-phase process, and several studies have tried to determine which coagulation stage is impaired in poorly and noncoagulating milk (van Hooydonk et al., 1986; Resmini et al., 1995; Frederiksen et al., 2011a). The first phase of the coagulation process, the enzymatic rennet-induced cleavage of $\kappa-\mathrm{CN}$ into an insoluble para- $\kappa-\mathrm{CN}(\kappa-\mathrm{CN}$ peptide 1-105) and a soluble hydrophilic caseinomacropeptide (CMP; $\kappa-\mathrm{CN}$ peptide 106-169), does not seem to be the primary cause of impaired coagulation. Frederiksen et al. (2011a) evaluated the generation of CMP and found a rapid generation of CMP in both poorly and noncoagulating milk, which is in agreement with other studies (van Hooydonk et al., 1986; Resmini et al., 1995). Whereas the first phase is believed to destabilize the $\mathrm{CN}$ micelles by reducing the steric protection provided by the negatively charged CMP of $\kappa$-CN located on the surface of the CN micelles (Chaplin and Green, 1980; Sandra et al., 2007), the second aggregation phase of rennet-induced milk coagulation is nonenzymatic. When a major part of the $\kappa-\mathrm{CN}$ is hydrolyzed ( $\approx 60$ to $90 \%$ ), the destabilized $\mathrm{CN}$ micelles begin a spontaneous aggregation, resulting in a gel-like network, that is, the curd or coagulum (Dalgleish, 1979; Lomholt and Qvist, 1997).

Although the milk composition of individual milk samples with impaired coagulation or noncoagulation ability has been increasingly studied (Okigbo et al., 1985; Ikonen et al., 1999, 2004; Wedholm et al., 2006; Joudu et al., 2007; Frederiksen et al., 2011a), the cause of the phenomenon is not yet fully understood. Technological properties of bovine milk measured by oscillatory rheology include curd firmness. Curd firmness is defined by coagulum strength $\left(\mathbf{G}^{\prime}{ }_{\text {max }}\right)$ and curd firming rate (CFR), which are closely related and depend mainly on CN concentration and composition (Wedholm et al., 2006; Hallén et al., 2007), whereas the relation to another technological property, namely, rennet coagulation time (RCT), is more subtle and not completely correlated (Wedholm et al., 2006; Frederiksen et al., 2011b). Rennet coagulation time must thus be influenced by multiple factors. Furthermore, is has been shown that poorly coagulating milk (i.e., milk forming a weak coagulum), but not milk with a long $\mathrm{RCT}$, is associated with a lower cheese yield (Wedholm et al., 2006).
The role of mineral salts in the CN micelle structure and in the milk coagulation process is fundamental (Holt, 1992; Fox, 2009). Impaired clotting properties have, among others, been linked to a lower content of the main cations in milk, including $\mathrm{Ca}$ and $\mathrm{Mg}$, along with a lower content of the main anion, inorganic P (Tervala and Antila 1985; van Hooydonk et al., 1986; Tsioulpas et al., 2007; Frederiksen et al., 2011a), and to a higher citrate content (Sundekilde et al., 2011). The minerals in milk exist in a dynamic equilibrium between the soluble serum phase and the colloidal micellar phase. This mineral distribution is influenced by several factors, such as cooling, lower milk $\mathrm{pH}$, and higher citrate content, all of which will lead to the dissolution of calcium phosphate, along with the dissolution of small amounts of $\mathrm{Mg}$ and citrate, from the micellar phase (Gaucheron, 2005), thus negatively influencing the milk coagulation properties.

Apart from environmental factors, evidence of a genetic contribution to milk coagulation has been confirmed, with the most consistent results in agreement that the $\mathrm{B}$ variants of $\kappa-\mathrm{CN}, \beta-\mathrm{CN}$, and $\beta-\mathrm{LG}$ are favorable for milk renneting and cheese manufacture (Ikonen et al., 1997, 1999; Di Stasio and Mariani, 2000; Wedholm et al., 2006; Hallén et al., 2007, 2008; Jensen et al., 2012).

The major milk proteins are heterogeneous because of genetic polymorphism and posttranslational modifications (PTM). More than 35 different milk protein variants have been identified (for reviews, see Di Stasio and Mariani, 2000; Farrell et al., 2004; Caroli et al., 2009). Phosphorylation catalyzed by specific CN kinases occurs in all CN molecules. The degree of phosphorylation, however, is highest in $\alpha_{\mathrm{S}^{-}}, \alpha_{\mathrm{S}^{-}}$, and $\beta-\mathrm{CN}$ and is low in $\mathrm{k}-\mathrm{CN}$. The phosphate groups are esterified to the CN via the hydroxyl groups mainly of Ser residues, making pSer, which in turn can bind colloidal calcium phosphate. Because of their hydrophilicity and strong Ca-binding properties, the pSer clusters on the $\mathrm{CN}$ are important for the physical and chemical properties of the $\mathrm{CN}$ micelles. The $\mathrm{CN}$ phosphorylation level has been proposed as contributing to stability against aggregation in the second phase of rennet-induced coagulation (Feagan et al., 1972; Frederiksen et al., 2011a). Unlike the other $\mathrm{CN}, \mathrm{\kappa}-\mathrm{CN}$ is glycosylated, which has been suggested to stabilize the $\mathrm{CN}$ micelles against aggregation through steric and electrostatic repulsion (Holt, 1992; Horne, 1998; Walstra, 1999). It has earlier been hypothesized that variations in glycosylation of $\kappa$-CN could influence the coagulation properties of milk (Tyrisevä et al., 2008).

We have recently conducted a 2-dimensional gelbased study in which 6 isoforms of $\kappa$-CN varying in levels of phosphorylation and glycosylation were resolved 
and a rather consistent distribution of $\kappa$ - $\mathrm{CN}$ isoforms in individual cow milk samples in relation to coagulation was found (Jensen et al., 2012). Although this gel-based approach gave a very high resolution of the $\kappa-\mathrm{CN}$ isoforms, the quantification that can be obtained by 2-dimensional gels is limited because of a relatively poor dynamic range. Therefore, it is of interest to study the PTM pattern of $\mathrm{CN}$ by using a liquid chromatography (LC)-based method for improved quantification (Domon and Aebersold, 2006) because knowledge is lacking about variation in the degree of PTM of milk proteins in relation to coagulation ability.

The objective was thus to study the rennet-induced milk coagulation of bovine milk in relation to genetic variation of the major milk proteins by using an LCbased method, along with variation in milk and mineral composition in milk samples selected to represent extremes in coagulation ability. Analyzing this distinctive milk subset together with a large number of parameters provided unique information on the underlying causes of poorly coagulating and noncoagulating milk.

\section{MATERIALS AND METHODS}

\section{Sample Collection}

Morning milk was obtained from 892 individual Danish cows (456 Holstein-Friesians and 436 Jerseys) collected from 42 herds in Jutland, Denmark, as described previously (Jensen et al., 2012). All cows were in midlactation (lactation wk 19 to 32 ), in parity 1 to 3 , housed in loose-housing systems, fed according to standard practice, and milked twice a day. Milk yield in the actual milking $(\mathrm{kg})$ from the cows was recorded for each milk sample collected.

\section{Milk Composition}

Immediately after the morning milking, milk samples were placed on ice for transport to the laboratory. Once at the laboratory, whole milk samples from the individual cows were analyzed in duplicate for concentrations of milk fat, protein, $\mathrm{CN}$, lactose, citrate, and urea by a MilkoScan FT2 instrument (Foss Electric, Hillerød, Denmark) and for SCC by flow cytometry using a Fossomatic 5000 instrument (Foss Electric) at Eurofins Laboratory (Holstebro, Denmark). Samples with an SCC $>500 \times 10^{3} \mathrm{cell} / \mathrm{mL}$ were excluded from further study. All milk samples were skimmed (centrifuged for 30 min at $2,643 \times g, 4^{\circ} \mathrm{C}$ ), followed by measurements of conductivity and $\mathrm{pH}$ using an LDM 210 conductivity meter (RadioMeter, Copenhagen, Denmark) and a PHM 220 pH meter (RadioMeter), respectively.

\section{Dynamic Rheological Analysis}

The skim milk was refrigerated for up to $6 \mathrm{~h}$ without preservatives before being subjected to rheological analysis the same day as collected. Dynamic rheological analyses were carried out in duplicate by measuring rennet-induced milk coagulation using a ReoRox 4 rheometer (MediRox AB, Nyköping, Sweden) essentially as described earlier (Frederiksen et al., 2011b). The technological properties $\mathrm{RCT}, \mathrm{G}_{\max }^{\prime}$, and $\mathrm{CFR}$ were selected to describe the coagulation properties of the individual milk samples. In short, the skim milk samples were preincubated for $30 \mathrm{~min}$ in a water bath at $33^{\circ} \mathrm{C}$ before addition of chymosin (ChyMax Ultra, Chr. Hansen Laboratories A/S, Hørsholm, Denmark) to a final concentration of 0.0388 international milk clotting units/mL of skim milk. Rheological measurements were performed at $33^{\circ} \mathrm{C}$ for $1 \mathrm{~h}$.

\section{Milk Sample Subset}

A milk sample subset representing the most extreme samples from the large screening with regard to rennetinduced coagulation defined the coagulation classes: good, poor, and none (Jersey: good, $\mathrm{n}=27$; poor, $\mathrm{n}=$ 25; Holstein-Friesian: good, $\mathrm{n}=26$; poor, $\mathrm{n}=18$; none, $\mathrm{n}=6$ ). The samples were selected based exclusively on the rheological analysis with respect to both RCT and CFR and were selected as extremes separately within each breed. The $\mathrm{G}^{\prime}{ }_{\max }$ was monitored but was not included in the selection criteria for coagulation grouping because of technical difficulties in the measurements of samples with high values, as especially observed for the Jersey milk samples (Frederiksen et al., 2011b). No significant variability was identified in SCC or actual milk yield between the coagulation classes within each breed (data not shown).

\section{Determination of Mineral Contents of $P, C a$, and $M g$}

The content of $\mathrm{P}$ in all milk samples was determined in duplicate by a vanadomolybdate colorimetric procedure (Stuffins, 1967), and the contents of $\mathrm{Ca}$ and $\mathrm{Mg}$ were obtained by atomic absorption spectrophotometry (Atomic Absorption System SP9; Pye Unicam Ltd., Cambridge, CB12 PX, UK). High-speed centrifugation was performed on skim milk from the milk sample subset to separate the soluble and the colloidal phases. The separation was performed at $150,000 \times g$ for $1 \mathrm{~h}$ at $4^{\circ} \mathrm{C}$ using a Beckman-Coulter Optima L-80XP Ultracentrifuge (Beckman Coulter Inc., Brea, CA). Total mineral $(\mathrm{Ca}, \mathrm{P}$, or $\mathrm{Mg})$ content was measured in skim milk. Soluble mineral (Ca, P, or $\mathrm{Mg}$ ) content was measured in ultracentrifuged supernatant milk serum. 


\section{Proteomic Profiling of Milk Proteins}

The LC/electrospray ionization-mass spectrometry (LC/ESI-MS) procedure used in the present study was developed based on previous studies (Bobe et al., 1998; Bonfatti et al., 2008; Bonizzi et al., 2009) and modified according to the method of Frederiksen et al. (2011a). Variations in the major milk proteins were determined using a reversed-phase LC-based method, in which the genetic variants and isoform PTM of selected proteins were identified by ESI/MS. Proteins were separated by a reversed-phase method using an HPLC 1100 system (Agilent Technologies, Santa Clara, CA) with a Jupiter C4 column $(250 \times 2 \mathrm{~mm}, 5-\mu \mathrm{m}$ particle size, $300 \AA$ pores; Phenomenex, Torrance, CA) operated at $40^{\circ} \mathrm{C}$ and a $\mathrm{G} 1315 \mathrm{~A}$ diode array detector with UV detection at $214 \mathrm{~nm}$ coupled to a mass selective detector for identification and relative quantification of the milk proteins. Average molecular masses $\left(\mathbf{M}_{\mathbf{w}}\right)$ of the milk proteins were obtained using the deconvolution algorithm of the ChemStation software (rev.B.04.01 SP [650]; Agilent Technologies). The procedures for sample preparation and settings for the HPLC, ESI source, and mass selective detector were as described by Frederiksen et al. (2011a). All milk samples were analyzed in duplicate. Method reproducibility was determined by calculating the coefficient of variation of the relative amounts of individual milk proteins in a reference milk sample, run as part of each separate HPLC series. The relative protein content of the major milk proteins was calculated as the integrated peak area of a certain compound compared with the total integrated peak area in each LC chromatogram of the individual milk samples.

\section{Statistical Analysis}

The data obtained for the various milk components, production parameters, and coagulation properties were subjected to statistical analysis by the generalized linear models (GLM) procedure of the SAS software program (version 9.2; SAS Institute Inc., Cary, NC). A model of one class variable, namely, the coagulation class (good, poor, or none), was used for each breed (Jersey or Holstein-Friesian) to calculate least squares mean values and standard errors. The model of analysis was

$$
Y_{i j}=a_{i}+e_{i j}
$$

where $a$ is the main effect of coagulation class $i$ (good, poor, none) and $e$ is the replicate $j(1, \ldots$, n). The $F$-test was performed to evaluate differences between the milk samples in the coagulation classes, using significance levels of 95, 99, and 99.9\% (i.e., $P<0.05, P<$
0.01 , and $P<0.001$ ), and differences were classified using the Ryan-Einot-Gabriel-Welsch multiple range test.

\section{RESULTS}

\section{Rheological Properties}

The rheological data of the milk subset selected from individual Jersey and Holstein-Friesian cows representing different coagulation classes are shown in Table 1. All coagulation classes were statistically different. The milk samples with good coagulation properties were defined by having a low RCT, a high CFR, and a high $\mathrm{G}_{\max }^{\prime}$, thus forming a strong coagulum within the measurement period. On the contrary, samples defined as poorly coagulating formed a very weak coagulum, as indicated by high RCT, low $\mathrm{CFR}$, and low $\mathrm{G}_{\text {max }}$ values. In addition, 6 Holstein-Friesian samples were noncoagulating, unable to form a coagulum within 1 $\mathrm{h}$ after addition of rennet, and thus having an RCT value $>60$ min along with $\mathrm{G}_{\text {max }}^{\prime}$ and $\mathrm{CFR}$ values of zero. Breed comparison revealed that milk from Jersey cows generally exhibited superior coagulation properties when compared with milk from Holstein-Friesian cows, as reflected in higher $\mathrm{CFR}$ and $\mathrm{G}^{\prime}{ }_{\max }$ values of Jersey milk samples in both coagulation classes.

\section{Milk Composition}

Table 2 shows milk composition in relation to coagulation class and breed, as determined by MilkoScan analysis of all individual milk samples in the subset. For both breeds, significantly lower contents of total protein and total CN were identified in both poorly coagulating and noncoagulating milk compared with milk having good coagulation ability. In Jersey milk, significant lower $\mathrm{pH}$ was identified in poorly coagulating milk, whereas in poorly coagulating and noncoagulating Holstein-Friesian milk, a significantly lower fat content was identified, with the CN number being higher in poorly coagulating Holstein-Friesian milk. No differences in milk composition were found between poorly coagulating and noncoagulating Holstein-Friesian milk.

\section{Mineral Composition}

Table 3 shows the mineral (Ca, P, Mg) composition in relation to coagulation class and breed. The overall trend was for lower amounts of minerals in milk with impaired coagulation properties for both breeds compared with milk that coagulated well, whereas no significant differences were observed between poorly coagulating and noncoagulating Holstein-Friesian milk. For Jersey milk, significantly lower amounts of total 
Table 1. Dynamic rheological data (least squares mean $\pm \mathrm{SE}$ ) defining milk coagulation classes in relation to breed

\begin{tabular}{|c|c|c|c|c|c|c|c|c|c|}
\hline \multirow[b]{2}{*}{$\begin{array}{l}\text { Coagulation } \\
\text { measurement }^{1}\end{array}$} & \multicolumn{2}{|c|}{ Jersey } & \multirow{2}{*}{$\begin{array}{c}\text { Significance }^{2} \\
\text { Good } \\
\text { vs. poor }\end{array}$} & \multicolumn{3}{|c|}{ Holstein-Friesian } & \multicolumn{3}{|c|}{ Significance $^{3}$} \\
\hline & $\begin{array}{c}\text { Good } \\
(\mathrm{n}=27)\end{array}$ & $\begin{array}{c}\text { Poor } \\
(\mathrm{n}=25)\end{array}$ & & $\begin{array}{c}\text { Good } \\
(\mathrm{n}=26)\end{array}$ & $\begin{array}{c}\text { Poor } \\
(\mathrm{n}=18)\end{array}$ & $\begin{array}{l}\text { None } \\
(\mathrm{n}=6)\end{array}$ & $\begin{array}{c}\text { Good } \\
\text { vs. poor }\end{array}$ & $\begin{array}{c}\text { Good } \\
\text { vs. none }\end{array}$ & $\begin{array}{c}\text { Poor } \\
\text { vs. none }\end{array}$ \\
\hline RCT (min) & $13.34 \pm 0.85$ & $22.16 \pm 0.88$ & $* * *$ & $13.24 \pm 0.42$ & $25.53 \pm 0.51$ & $>60.0$ & $* * *$ & $* * *$ & $* * *$ \\
\hline CFR ( $\mathrm{Pa} / \mathrm{min})$ & $32.76 \pm 0.51$ & $10.51 \pm 0.53$ & $* * *$ & $18.82 \pm 0.45$ & $3.15 \pm 0.54$ & $0.0 \pm 0.94$ & *** & $* * *$ & *** \\
\hline $\mathrm{G}_{\text {max }}^{\prime}(\mathrm{Pa})$ & $799.94 \pm 40.02$ & $308.30 \pm 41.58$ & $* * *$ & $360.13 \pm 12.85$ & $91.22 \pm 15.45$ & $0.0 \pm 26.76$ & $* * *$ & $* * *$ & $* * *$ \\
\hline
\end{tabular}

${ }^{1}$ Rheological measurements were performed on all individual milk samples. $\mathrm{RCT}=$ rennet coagulation time; CFR $=$ curd firming rate; $\mathrm{G}_{\text {max }}=$ coagulum strength.

${ }^{2}$ Indicating variation between coagulation classes in Jersey milk.

${ }^{3}$ Indicating variation between coagulating classes in Holstein-Friesian milk.

$* * * P<0.001$. Significance values calculated based on $F$-test.

Table 2. Milk composition (least squares mean \pm SE) as a function of milk coagulation class and breed

\begin{tabular}{|c|c|c|c|c|c|c|c|c|c|}
\hline \multirow[b]{2}{*}{ Milk composition $^{1}$} & \multicolumn{2}{|c|}{ Jersey } & \multirow{2}{*}{$\begin{array}{c}\text { Significance }^{2} \\
\text { Good } \\
\text { vs. poor }\end{array}$} & \multicolumn{3}{|c|}{ Holstein-Friesian } & \multicolumn{3}{|c|}{ Significance $^{3}$} \\
\hline & $\begin{array}{c}\text { Good } \\
(\mathrm{n}=27)\end{array}$ & $\begin{array}{c}\text { Poor } \\
(\mathrm{n}=25)\end{array}$ & & $\begin{array}{c}\text { Good } \\
(\mathrm{n}=26)\end{array}$ & $\begin{array}{c}\text { Poor } \\
(\mathrm{n}=18)\end{array}$ & $\begin{array}{c}\text { None } \\
(\mathrm{n}=6)\end{array}$ & $\begin{array}{c}\text { Good } \\
\text { vs. poor }\end{array}$ & $\begin{array}{c}\text { Good } \\
\text { vs. none }\end{array}$ & $\begin{array}{c}\text { Poor } \\
\text { vs. none }\end{array}$ \\
\hline $\mathrm{pH}$ & $6.68 \pm 0.01$ & $6.62 \pm 0.01$ & ** & $6.69 \pm 0.02$ & $6.68 \pm 0.02$ & $6.68 \pm 0.04$ & NS & NS & NS \\
\hline Conductivity $(\mathrm{S} / \mathrm{cm})$ & $5.43 \pm 0.06$ & $5.56 \pm 0.06$ & NS & $5.71 \pm 0.10$ & $5.94 \pm 0.12$ & $5.80 \pm 0.20$ & NS & NS & NS \\
\hline Fat $(\mathrm{g} / 100 \mathrm{~g})$ & $6.05 \pm 0.23$ & $5.93 \pm 0.24$ & NS & $4.43 \pm 0.16$ & $3.69 \pm 0.19$ & $3.51 \pm 0.32$ & $* *$ & $*$ & NS \\
\hline Protein (g/100 g) & $4.49 \pm 0.04$ & $4.15 \pm 0.04$ & $* * *$ & $3.67 \pm 0.05$ & $3.30 \pm 0.05$ & $3.28 \pm 0.09$ & $* * *$ & $* * *$ & NS \\
\hline $\mathrm{CN}(\mathrm{g} / 100 \mathrm{~g})$ & $3.13 \pm 0.02$ & $2.93 \pm 0.02$ & $* * *$ & $2.77 \pm 0.02$ & $2.57 \pm 0.03$ & $2.55 \pm 0.05$ & $* * *$ & $* * *$ & NS \\
\hline CN number ${ }^{4}$ & $69.88 \pm 0.34$ & $70.50 \pm 0.36$ & NS & $75.51 \pm 0.52$ & $77.74 \pm 0.62$ & $77.83 \pm 1.08$ & $* *$ & NS & NS \\
\hline Lactose (g/100 g) & $4.62 \pm 0.04$ & $4.62 \pm 0.04$ & NS & $4.78 \pm 0.03$ & $4.75 \pm 0.04$ & $4.71 \pm 0.07$ & NS & NS & NS \\
\hline Urea $(\mathrm{m} M)$ & $2.70 \pm 0.12$ & $2.93 \pm 0.11$ & NS & $2.25 \pm 0.14$ & $2.46 \pm 0.17$ & $2.25 \pm 0.30$ & NS & NS & NS \\
\hline Citrate $(\mathrm{g} / \mathrm{kg})$ & $1.86 \pm 0.03$ & $1.79 \pm 0.03$ & NS & $1.62 \pm 0.05$ & $1.75 \pm 0.05$ & $1.73 \pm 0.09$ & NS & NS & NS \\
\hline
\end{tabular}

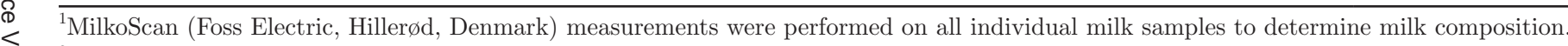

$\subseteq \quad{ }^{2}$ Indicating variation between coagulation classes in Jersey milk.

G $\quad{ }^{3}$ Indicating variation between coagulating classes in Holstein-Friesian milk.

Z ${ }^{4}$ Calculated as $(\mathrm{CN} /$ protein $) \times 100$.

$\vec{N} \quad * P<0.05 ;{ }^{* *} P<0.01 ; * * * P<0.001$. Significance values calculated based on $F$-test. 
$\mathrm{Ca}$, micellar $\mathrm{Ca}$, micellar $\mathrm{P}$, and micellar $\mathrm{P}$ relative to total $\mathrm{P}$ were observed in poorly coagulating milk. For Holstein-Friesians, significant lower amounts of minerals in both poorly coagulating and noncoagulating milk were total $\mathrm{Ca}$, micellar $\mathrm{Ca}$, micellar $\mathrm{P}$, and micellar $\mathrm{Mg}$.

\section{Identification of Genetic Variants and Isoforms of Milk Proteins}

Figure 1 shows comparative chromatograms of pooled milk samples from Jersey and Holstein-Friesian cows, respectively, in relation to the coagulation class. A high resolution of the major milk proteins was obtained, in which the proteins eluted in the following order: $\kappa-\mathrm{CN}$, $\alpha_{\mathrm{s} 2}-\mathrm{CN}, \alpha_{\mathrm{s} 1}-\mathrm{CN}, \beta-\mathrm{CN}, \beta-\mathrm{LG}$, and $\alpha-\mathrm{LA}$. The retention time of the proteins was found to be dependent on both genotype and degree of PTM. The $\kappa$-CN eluted in 3 major peaks; the first peak contained various glycosylated forms of $\kappa-\mathrm{CN}$ (average $\mathrm{M}_{\mathrm{w}}>19.000 \mathrm{Da}$ ), whereas the second peak contained unglycosylated $\kappa-\mathrm{CN}$ A-1P $\left(\mathrm{M}_{\mathrm{w}}=19,035 \mathrm{Da}\right)$ or $\kappa-\mathrm{CN} \mathrm{E}-1 \mathrm{P}\left(\mathrm{M}_{\mathrm{w}}=19,004 \mathrm{Da}\right)$, and the last peak contained unglycosylated forms of k-CN B-1P $\left(\mathrm{M}_{\mathrm{w}}=19,002 \mathrm{Da}\right)$. It was not possible to discriminate between $\kappa-\mathrm{CN} \mathrm{A}-1 \mathrm{P}$ and $\mathrm{E}-1 \mathrm{P}$ by using the chromatogram alone because these variants had similar retention times, but discrimination was possible by mass spectrometry analysis. The $\alpha_{\mathrm{s}^{2}} \mathrm{CN}$ A eluted in 2 major peaks, corresponding to varying states of phosphorylation, namely, $\alpha_{\mathrm{s} 2}-\mathrm{CN}$ A-11P $\left(\mathrm{M}_{\mathrm{w}}=25,224\right.$ Da) and $\alpha_{\mathrm{s} 2}-\mathrm{CN}$ A-12P $\left(\mathrm{M}_{\mathrm{w}}=25,304 \mathrm{Da}\right)$, in which the retention time was found to increase with an increasing degree of phosphorylation. The $\alpha_{\mathrm{s} 1}-\mathrm{CN}$ separated into a major peak containing 2 variants, identified as $\alpha_{\mathrm{s} 1}-\mathrm{CN}$ B-8P $\left(\mathrm{M}_{\mathrm{w}}=23,611 \mathrm{Da}\right)$ and $\alpha_{\mathrm{s} 1}-\mathrm{CN} \mathrm{C}-8 \mathrm{P}\left(\mathrm{M}_{\mathrm{w}}\right.$ $=23,539 \mathrm{Da})$, and a minor peak, also containing 2 variants, $\alpha_{\mathrm{s} 1}-\mathrm{CN}$ B-9P $\left(\mathrm{M}_{\mathrm{w}}=23,691 \mathrm{Da}\right)$ or $\alpha_{\mathrm{s} 1}-\mathrm{CN}$ C-9P $\left(\mathrm{M}_{\mathrm{w}}=23,619 \mathrm{Da}\right)$. Five different genetic variants of $\beta$-CN were identified: $\beta$-CN A ${ }^{1}-5 \mathrm{P}\left(\mathrm{M}_{\mathrm{w}}=24,020 \mathrm{Da}\right)$, $\beta-\mathrm{CN} \mathrm{A}^{2}-5 \mathrm{P}\left(\mathrm{M}_{\mathrm{w}}=23,980\right.$ Da), $\beta-\mathrm{CN}$ B-5P $\left(\mathrm{M}_{\mathrm{w}}=\right.$ $24,088 \mathrm{Da}), \beta-\mathrm{CN}$ F-5P $\left(\mathrm{M}_{\mathrm{w}}=24,033 \mathrm{Da}\right)$, and $\beta-\mathrm{CN}$ $\mathrm{I}-5 \mathrm{P}\left(\mathrm{M}_{\mathrm{w}}=23,963 \mathrm{Da}\right)$. The $\beta-\mathrm{CN}$ variants $\mathrm{A}^{2}-5 \mathrm{P}$ and $\mathrm{I}-5 \mathrm{P}$ eluted at the same time and were discriminated only by mass spectrometry analysis. The major whey proteins were also identified as corresponding to $\alpha$-LA $\mathrm{B}\left(\mathrm{M}_{\mathrm{w}}=14,184 \mathrm{Da}\right)$ and 3 variants of $\beta-\mathrm{LG}$, namely, $\beta-\mathrm{LG} \mathrm{A}\left(\mathrm{M}_{\mathrm{w}}=18,364 \mathrm{Da}\right), \beta-\mathrm{LG}$ B $\left(\mathrm{M}_{\mathrm{w}}=18,278 \mathrm{Da}\right)$, and $\beta-\mathrm{LG} \mathrm{C}\left(\mathrm{M}_{\mathrm{w}}=18,287 \mathrm{Da}\right)$.

\section{Distribution of Milk Protein Genetic Variants}

Table 4 summarizes the frequencies of the genetic variants of the major milk proteins identified in relation to coagulation class and breed. In both breeds, milk with impaired coagulation properties had similar distributions of the genetic variants of $\beta-\mathrm{CN}, \kappa-\mathrm{CN}$, and $\beta$-LG, with these samples having high frequencies of $\beta-\mathrm{CN} \mathrm{A}{ }^{2}, \kappa-\mathrm{CN} \mathrm{A}$, and $\beta$-LG A compared with milk that coagulated well. The $\alpha_{S^{2}}$ CN and $\alpha$-LA appeared monomorphic in the investigated milk subset of both breeds, with the identification of 1 variant per protein, such as $\alpha_{\mathrm{S}_{2}} \mathrm{CN}$ A and $\alpha$-LA B. In Jerseys, both the B and $\mathrm{C}$ variants of $\alpha_{S_{1}}-\mathrm{CN}$ were prominent in milk that coagulated well, whereas $\alpha_{S 1}$ CN variant $B$ dominated in poorly coagulating milk. In contrast, only 1 variant, $\alpha_{\mathrm{S} 1}-\mathrm{CN}$ variant $\mathrm{B}$, was identified in Holstein-Friesian milk independent of the coagulation class. It is interesting that the rare variants, $\beta-\mathrm{CN}$ I and $\mathrm{F}$ (only in Holstein-Friesian), $\kappa-\mathrm{CN}$ E, and $\beta$-LG C (only in Jersey), were also identified.

To summarize the genotyping of $\alpha_{\mathrm{S1}^{-}}, \beta-$, and $\kappa-\mathrm{CN}$, the most prevalent ( $\mathrm{n}=8$ out of a total of 27$)$ of the Jersey samples coagulating well had the composite CC- $\mathrm{A}^{2} \mathrm{~A}^{2}$-BB genotype, whereas the most prevalent (n $=7$ out of 25) of the poorly coagulating samples had the $\mathrm{BB}-\mathrm{A}^{2} \mathrm{~A}^{2}$-AA genotype. For the Holstein-Friesian milk samples, the most prevalent composite genotype of good coagulating samples $(\mathrm{n}=5$ out of 26$)$ was BB$\mathrm{A}^{1} \mathrm{~A}^{2}-\mathrm{AB}$. It is interesting that the majority of poorly coagulating samples $(\mathrm{n}=10$ out of 18$)$ and noncoagulating samples $(n=3$, out of 6$)$ were $B B-A^{2} A^{2}-A A$, identical to the composite genotype found in poorly coagulating Jersey milk.

\section{Relative Quantification of Milk Proteins}

Table 5 shows the relative protein composition of the major milk proteins identified in relation to coagulation class and breed, as determined by LC/ESI-MS analysis of individual milk samples. A fixed sample volume $(7 \mu \mathrm{L})$ was injected into the liquid chromatograph. Therefore, quantitative protein comparison was valid only within each breed and not between breeds; Jersey milk, among others, contained a higher amount of total protein (see Table 2), which gave marginal breed variation in the retention time of the protein profile in the LC chromatograms. For both breeds, however, the same trends emerged. This was seen because the amount of total CN was significantly lower in both poorly coagulating and noncoagulating milk compared with milk with good coagulating ability. This result was in accordance with the CN measurements obtained from the MilkoScan analysis (Table 2). In the relative quantification of total $\mathrm{CN}$, all peaks in the $\mathrm{CN}$ elution interval were integrated, whereas for the individual major proteins, only the large peaks identified as intact proteins (constituting all isoforms of the specific 
Table 3. Mineral composition (least squares mean $\pm \mathrm{SE}$ ) as a function of milk coagulation class and breed

\begin{tabular}{|c|c|c|c|c|c|c|c|c|c|}
\hline \multirow[b]{2}{*}{ Mineral $^{1}$} & \multicolumn{2}{|c|}{ Jersey } & \multirow{2}{*}{$\begin{array}{c}\text { Significance }^{2} \\
\text { Good } \\
\text { vs. poor }\end{array}$} & \multicolumn{3}{|c|}{ Holstein-Friesian } & \multicolumn{3}{|c|}{ Significance $^{3}$} \\
\hline & $\begin{array}{c}\text { Good } \\
(\mathrm{n}=27)\end{array}$ & $\begin{array}{c}\text { Poor } \\
(\mathrm{n}=25)\end{array}$ & & $\begin{array}{c}\text { Good } \\
(\mathrm{n}=26)\end{array}$ & $\begin{array}{c}\text { Poor } \\
(\mathrm{n}=18)\end{array}$ & $\begin{array}{l}\text { None } \\
(\mathrm{n}=6)\end{array}$ & $\begin{array}{c}\text { Good } \\
\text { vs. poor }\end{array}$ & $\begin{array}{c}\text { Good } \\
\text { vs. none }\end{array}$ & $\begin{array}{c}\text { Poor } \\
\text { vs. none }\end{array}$ \\
\hline Total Ca (mg/kg) & $1,632.04 \pm 23.08$ & $1,457.92 \pm 23.99$ & $* * *$ & $1,271.44 \pm 21.81$ & $1,120.16 \pm 26.21$ & 1,062.33. \pm 45.39 & $* * *$ & $* * *$ & NS \\
\hline Soluble Ca (mg/kg) & $534.09 \pm 25.67$ & $518.00 \pm 26.68$ & NS & $414.31 \pm 12.52$ & $383.44 \pm 15.05$ & $358.58 \pm 26.06$ & NS & NS & NS \\
\hline Micellar $\mathrm{Ca}(\mathrm{mg} / \mathrm{kg})$ & $1,097.94 \pm 24.74$ & $939.92 \pm 25.71$ & $* * *$ & $857.13 \pm 23.68$ & $736.72 \pm 28.46$ & $703.75 \pm 49.29$ & $* *$ & $* *$ & NS \\
\hline $\begin{array}{c}\text { Micellar Ca relative } \\
\text { to total } \mathrm{Ca}(\%)\end{array}$ & $66.43 \pm 1.59$ & $64.41 \pm 1.65$ & NS & $67.25 \pm 1.23$ & $65.66 \pm 1.10$ & $65.90 \pm 3.82$ & $* * *$ & NS & NS \\
\hline Total P (mg/kg) & $1,189.74 \pm 18.03$ & $1,196.38 \pm 18.73$ & NS & $967.59 \pm 23.27$ & $892.81 \pm 27.97$ & $922.67 \pm 48.45$ & * & NS & NS \\
\hline Soluble P (mg/kg) & $492.07 \pm 11.98$ & $558.26 \pm 12.45$ & $* * *$ & $440.79 \pm 12.73$ & $432.62 \pm 15.30$ & $483.58 \pm 26.51$ & NS & NS & NS \\
\hline Micellar P (mg/kg) & $697.67 \pm 15.58$ & $638.12 \pm 16.19$ & $* *$ & $526.81 \pm 16.46$ & $460.19 \pm 19.79$ & $439.08 \pm 34.27$ & $*$ & $*$ & NS \\
\hline $\begin{array}{l}\text { Micellar } \mathrm{P} \text { relative } \\
\text { to total } \mathrm{P}(\%)\end{array}$ & $58.65 \pm 0.90$ & $53.19 \pm 0.94$ & $* * *$ & $54.21 \pm 0.96$ & $51.55 \pm 0.97$ & $47.22 \pm 3.33$ & $*$ & NS & NS \\
\hline Total Mg (mg/kg) & $128.77 \pm 2.48$ & $128.16 \pm 2.57$ & NS & $111.09 \pm 2.31$ & $105.50 \pm 2.77$ & $98.41 \pm 4.80$ & NS & * & NS \\
\hline Soluble $\mathrm{Mg}(\mathrm{mg} / \mathrm{kg})$ & $90.16 \pm 2.27$ & $91.80 \pm 2.36$ & NS & $80.27 \pm 1.84$ & $79.39 \pm 2.21$ & $74.33 \pm 3.83$ & NS & NS & NS \\
\hline Micellar $\mathrm{Mg}(\mathrm{mg} / \mathrm{kg})$ & $38.61 \pm 1.55$ & $36.36 \pm 1.61$ & NS & $30.82 \pm 1.32$ & $26.11 \pm 1.59$ & $24.08 \pm 2.76$ & $*$ & * & NS \\
\hline $\begin{array}{l}\text { Micellar } \mathrm{Mg} \text { relative } \\
\text { to total } \mathrm{Mg}(\%)\end{array}$ & $30.21 \pm 0.99$ & $28.08 \pm 1.03$ & NS & $27.62 \pm 0.99$ & $24.80 \pm 0.15$ & $24.22 \pm 2.27$ & $* * *$ & NS & NS \\
\hline
\end{tabular}

${ }^{1}$ Mineral contents were measured in all individual milk samples. Total mineral content was measured in skim milk. Soluble mineral content was measured in ultracentrifuged supernatant milk serum. Micellar mineral content was calculated as (total - soluble content). Micellar mineral relative to total mineral content was calculated as (micellar/total mineral) $\times 100$

ᄃ. ${ }^{2}$ Indicating variation between coagulation classes in Jersey milk.

${ }^{3}$ Indicating variation between coagulating classes in Holstein-Friesian milk.

을 $\quad * P<0.05 ;{ }^{* *} P<0.01 ;{ }^{* * *} P<0.001$. Significance values calculated based on $F$-test. 
protein; see Figure 1) were integrated and compared with the total protein profile. In addition, another common trend for both breeds was the significantly lower amount of $\kappa_{-}-\mathrm{CN}$ in poorly coagulating and noncoagulating milk observed in the protein profile of the LC chromatograms. The same result was obtained when $\kappa-\mathrm{CN}$ was expressed as a percentage of the total CN content (data not shown).

The chromatograms also revealed interesting information about variations in PTM of CN. In Figure 2A, the respective chromatograms of pooled Holstein-Friesian milk samples in relation to coagulation class have been enlarged in the elution interval of $\alpha_{\mathrm{S}_{1}-} \mathrm{CN}$. Although the 2 peaks were not completely separated, it was possible to distinguish between the 2 phosphorylation forms (8P and $9 \mathrm{P}$ ) of $\alpha_{\mathrm{S}^{-}} \mathrm{CN}$, with relative quantification revealing that poorly coagulating and noncoagulating milk had significantly smaller fractions of $\alpha_{\mathrm{S}_{1}} \mathrm{CN} 8 \mathrm{P}$ compared with milk with good coagulation ability (Figure 2B). Figure 3A shows chromatograms of pooled HolsteinFriesian milk samples in relation to coagulation class enlarged in the elution interval of $\kappa-\mathrm{CN}$. The $\kappa-\mathrm{CN}$ eluted in 3 major peaks, corresponding to 1 peak with glycosylated forms and 2 peaks containing distinct unglycosylated genetic variants (A/E and B). Compared with milk with good coagulation ability, relative quantification revealed a tendency $(P=0.09)$ for poorly coagulating and noncoagulating Holstein-Friesian milk to have a lower fraction of glycosylated $\kappa-\mathrm{CN}$ (Figure 3B). This PTM analysis of both $\alpha_{\mathrm{S}_{1}} \mathrm{CN}$ and $\kappa-\mathrm{CN}$ was also conducted in Jersey samples in relation to coagulation classes and showed the same trends as above, although they were not significant (data not shown).

\section{DISCUSSION}

This investigation showed variation in the overall milk, mineral, and protein composition in relation to rennet-induced coagulation properties of milk from individual Danish Jersey and Holstein-Friesian cows. The samples represented extremes with regard to coagulation properties, in which milk from Jersey cows generally exhibited superior coagulation properties compared with milk from Holstein-Friesian cows, which is in agreement with other studies (Frederiksen et al., 2011b). This result is most likely explained by the higher protein content in Jersey milk compared with that of Holstein-Friesian milk (Table 1) because it is well documented that protein content is positively associated with good rennet-induced coagulation ability (Wedholm et al., 2006) and especially CFR (Frederiksen et al., 2011b). The main findings of the present study include significant differences in milk composition between the coagulation classes for both breeds,
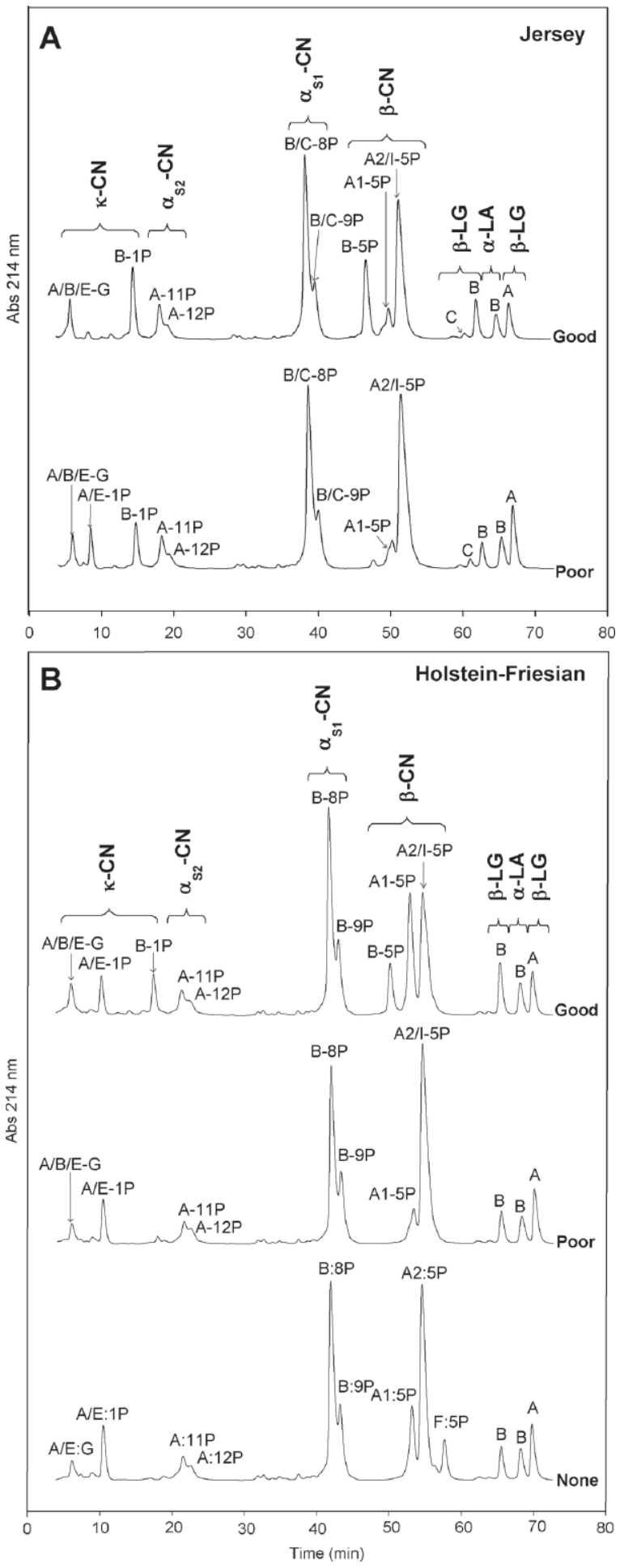

Figure 1. Comparison and identification of genetic variants and isoforms of major milk proteins in relation to coagulation class and breed. (A) Chromatograms of pooled Jersey milk with good or poor coagulation ability (good, $\mathrm{n}=27$; poor, $\mathrm{n}=25$ ). (B) Chromatograms of pooled Holstein-Friesian milk with good, poor, or noncoagulation ability (good, $\mathrm{n}=26$; poor, $\mathrm{n}=18$; none, $\mathrm{n}=6$ ). All identified milk proteins (vertical text) are marked, along with genetic variants and posttranslational modifications (horizontal text; $\mathrm{G}=$ glycan, $\mathrm{P}=$ phosphate group).. 
Table 4. Frequencies of genetic variants of the major milk proteins as function of milk coagulation class and breed

\begin{tabular}{|c|c|c|c|c|c|c|}
\hline \multirow[b]{2}{*}{ Protein $^{1}$} & \multirow[b]{2}{*}{$\begin{array}{l}\text { Genetic } \\
\text { variant }\end{array}$} & \multicolumn{2}{|c|}{ Jersey } & \multicolumn{3}{|c|}{ Holstein-Friesian } \\
\hline & & $\begin{array}{c}\text { Good } \\
(\mathrm{n}=27)\end{array}$ & $\begin{array}{c}\text { Poor } \\
(\mathrm{n}=25)\end{array}$ & $\begin{array}{c}\text { Good } \\
(\mathrm{n}=26)\end{array}$ & $\begin{array}{c}\text { Poor } \\
(\mathrm{n}=18)\end{array}$ & $\begin{array}{l}\text { None } \\
(\mathrm{n}=6)\end{array}$ \\
\hline \multirow[t]{2}{*}{$\alpha_{\mathrm{S}_{1}-\mathrm{CN}}$} & $\mathrm{B}$ & 0.519 & 0.760 & 1.000 & 1.000 & 1.000 \\
\hline & $\mathrm{C}$ & 0.481 & 0.240 & 0.000 & 0.000 & 0.000 \\
\hline \multirow{6}{*}{$\begin{array}{l}\alpha_{\mathrm{S}_{2}-\mathrm{CN}} \\
\beta-\mathrm{CN}\end{array}$} & A & 1.000 & 1.000 & 1.000 & 1.000 & 1.000 \\
\hline & $\mathrm{A}^{1}$ & 0.130 & 0.100 & 0.327 & 0.111 & 0.167 \\
\hline & $\mathrm{A}^{2}$ & 0.556 & 0.740 & 0.365 & 0.778 & 0.750 \\
\hline & B & 0.240 & 0.040 & 0.135 & 0.000 & 0.000 \\
\hline & I & 0.074 & 0.120 & 0.173 & 0.111 & 0.000 \\
\hline & $\mathrm{F}$ & 0.000 & 0.000 & 0.000 & 0.000 & 0.083 \\
\hline \multirow[t]{3}{*}{$\kappa-\mathrm{CN}$} & A & 0.074 & 0.480 & 0.442 & 0.861 & 0.833 \\
\hline & B & 0.907 & 0.460 & 0.519 & 0.111 & 0.000 \\
\hline & $\mathrm{E}$ & 0.019 & 0.060 & 0.038 & 0.028 & 0.167 \\
\hline$\alpha-L A$ & B & 1.000 & 1.000 & 1.000 & 1.000 & 1.000 \\
\hline \multirow[t]{3}{*}{$\beta-\mathrm{LG}$} & A & 0.444 & 0.560 & 0.385 & 0.583 & 0.500 \\
\hline & B & 0.537 & 0.360 & 0.615 & 0.417 & 0.500 \\
\hline & $\mathrm{C}$ & 0.019 & 0.080 & 0.000 & 0.000 & 0.000 \\
\hline
\end{tabular}

${ }^{1}$ Protein and genetic variant identification of the major milk proteins were determined in all individual milk samples by liquid chromatography/electrospray ionization-mass spectrometry.

showing lower total protein and total $\mathrm{CN}$ in poorly coagulating and noncoagulating milk compared with milk with good coagulation ability. This is important in relation to cheese yield because previous studies have shown that cheese yield is positively correlated with CN concentration (Wedholm et al., 2006; Hallén et al., 2010; Frederiksen et al., 2011a).

Additionally, the mineral content in milk is known to have an influence on milk coagulation ability (Tervala and Antila 1985; Tsioulpas et al., 2007), in which milk with impaired clotting properties has been shown to be improved by the addition of $\mathrm{CaCl}_{2}$; that is, the addition of $\mathrm{CaCl}_{2}$ reduced $\mathrm{RCT}$ and, in particular, increased CFR (Hallén et al., 2010). The mineral composition and distribution found in the present study were within the range reported in other studies (Hallén et al., 2010; Frederiksen et al., 2011a). These results not only confirm the lower amounts of $\mathrm{Ca}, \mathrm{P}$, and $\mathrm{Mg}$ in poorly coagulating and noncoagulating milk, in agreement with other studies (Tervala and Antila 1985; van Hooydonk et al., 1986; Tsioulpas et al., 2007; Frederiksen et al., 2011a), but also confirm overall that lower fractions of these minerals were micellar (i.e., bound to the $\mathrm{CN}$ micelles) in milk with impaired coagulation ability. A likely consequence of the lower mineral content would be an increase in the hydrophilicity of the Ca-sensitive CN $\left(\alpha_{\mathrm{S1}^{-}}, \alpha_{\mathrm{S} 2^{-}}, \beta-\mathrm{CN}\right)$ in the hydrophobic core of the CN micelles, as shown by Resmini et al. (1995), which could destabilize the CN micelle structure and thus possibly affect the second aggregation phase of rennetinduced coagulation.
To reveal the patterns of genetic variation in relation to the coagulation properties of milk, a comparison of the distribution of the genetic variants of the major milk proteins was conducted. The most common genetic variants of the major milk proteins confirmed earlier studies on Danish dairy breeds (Lien et al., 1999). Interestingly, low-frequency variants $\beta-\mathrm{CN} \mathrm{I}, \kappa-\mathrm{CN} \mathrm{E}$ and $\beta$-LG C were also identified in accordance with other studies (Hallén et al., 2007, 2008; Jensen et al., 2012), as well as a variant that, to our knowledge, has not previously been identified in milk from Danish dairy cows; that is, $\beta$-CN F. As shown by Jensen et al. (2012), analyzing a small number (48 samples) of the analyzed milk samples in the present study (102 samples), clear differences in the frequencies of the identified genetic variants were evident between coagulation classes and breeds. In agreement with the obtained results, the B variants of $\beta-\mathrm{CN}, \kappa-\mathrm{CN}$, and $\beta-\mathrm{LG}$ are considered favorable for milk coagulation and cheese making (Ikonen et al., 1997, 1999; Di Stasio and Mariani, 2000; Wedholm et al., 2006; Hallén et al., 2007, 2008; Jensen et al., 2012 ), whereas $\beta-\mathrm{CN} \mathrm{A}{ }^{2}, \kappa-\mathrm{CN} \mathrm{A}$ and $\mathrm{E}$, and $\beta$-LG A are associated with poor coagulation and noncoagulation abilities (Ikonen et al., 1999; Hallén et al., 2007; Jensen et al., 2012). Furthermore, $\alpha_{\mathrm{S1}^{-}} \mathrm{CN} \mathrm{C}$ was identified at a high frequency only in Jersey milk with good coagulation ability; this variant that has been reported to be related to a higher CN content and more favorable CN number (Graml et al., 1985), along with better coagulation characteristics (Oloffs et al., 1992; Di Stasio and Mariani, 2000). 
Table 5. Relative protein composition [least squares mean $(\%) \pm \mathrm{SE}$ ] as function of milk coagulation class and breed

\begin{tabular}{|c|c|c|c|c|c|c|c|c|c|}
\hline \multirow[b]{2}{*}{$\begin{array}{l}\text { rotein or } \\
\text { raction }^{1}\end{array}$} & \multicolumn{2}{|c|}{ Jersey } & \multirow{2}{*}{$\begin{array}{c}\text { Significance }^{2} \\
\text { Good } \\
\text { vs. poor }\end{array}$} & \multicolumn{3}{|c|}{ Holstein-Friesian } & \multicolumn{3}{|c|}{ Significance $^{3}$} \\
\hline & $\begin{array}{c}\text { Good } \\
(\mathrm{n}=27)\end{array}$ & $\begin{array}{c}\text { Poor } \\
(\mathrm{n}=25)\end{array}$ & & $\begin{array}{c}\text { Good } \\
(\mathrm{n}=29)\end{array}$ & $\begin{array}{c}\text { Poor } \\
(\mathrm{n}=18)\end{array}$ & $\begin{array}{c}\text { None } \\
(\mathrm{n}=6)\end{array}$ & $\begin{array}{c}\text { Good } \\
\text { vs. poor }\end{array}$ & $\begin{array}{c}\text { Good } \\
\text { vs. none }\end{array}$ & $\begin{array}{c}\text { Poor } \\
\text { vs. none }\end{array}$ \\
\hline otal CN & $78.08 \pm 1.70$ & $72.36 \pm 1.32$ & $*$ & $83.23 \pm 0.49$ & $81.11 \pm 0.59$ & $81.37 \pm 1.02$ & $* *$ & NS & NS \\
\hline $\mathrm{S} 1-\mathrm{CN}$ & $25.75 \pm 0.84$ & $23.70 \pm 0.83$ & NS & $24.66 \pm 0.71$ & $23.62 \pm 0.85$ & $22.70 \pm 1.47$ & NS & NS & NS \\
\hline${ }_{\mathrm{S} 2}-\mathrm{CN}$ & $5.25 \pm 0.17$ & $6.03 \pm 0.17$ & $* *$ & $5.35 \pm 0.15$ & $5.32 \pm 0.18$ & $5.89 \pm 0.31$ & NS & NS & NS \\
\hline$-\mathrm{CN}$ & $31.59 \pm 0.70$ & $29.73 \pm 0.71$ & NS & $34.36 \pm 0.76$ & $33.28 \pm 0.92$ & $32.94 \pm 1.59$ & NS & NS & NS \\
\hline$-\mathrm{CN}$ & $9.51 \pm 0.50$ & $7.48 \pm 0.50$ & $* *$ & $10.85 \pm 0.22$ & $8.19 \pm 0.27$ & $8.60 \pm 0.47$ & $* * *$ & $* * *$ & NS \\
\hline$-\mathrm{LA}$ & $2.38 \pm 0.10$ & $2.73 \pm 0.11$ & * & $3.18 \pm 0.31$ & $3.06 \pm 0.38$ & $2.88 \pm 0.65$ & NS & NS & NS \\
\hline -LG & $6.75 \pm 0.27$ & $7.18 \pm 0.30$ & NS & $6.51 \pm 0.28$ & $7.33 \pm 0.33$ & $7.44 \pm 0.58$ & NS & NS & NS \\
\hline
\end{tabular}

ก $\beta$-LG $\quad 6.75 \pm 0.27 \quad 7.18 \pm 0.30$ ${ }^{1}$ The major milk proteins were quantified in all individual milk samples using liquid chromatography/electrospray ionization-mass spectrometry. Total CN comprises all peaks in
the CN elution interval of the chromatogram (Jersey: 5 to $57 \mathrm{~min}$; Holstein-Friesian: 5 to 62 min; cf. Figure 1 ), namely, the intact $\mathrm{CN}\left(\alpha_{\mathrm{S}^{-}}, \alpha_{\mathrm{S}^{-}}, \beta_{-}\right.$, and $\left.\kappa-\mathrm{CN}\right)$, proteolytic $\mathrm{CN}$ degradation products (i.e., $\gamma-\mathrm{CN}$ ), and several $\kappa$-CN glycosylation isoforms previously identified (Bobe et al., 1998; Bonfatti et al., 2008; Bonizzi et al., 2009). On the contrary, the individual proteins comprise only the peaks identified as intact proteins and isoforms marked in Figure 1 ; that is, $\alpha_{\mathrm{S1}}-\mathrm{CN}\left(\operatorname{comprises} \alpha_{\mathrm{S1}}-\mathrm{CN} 8 \mathrm{P}+9 \mathrm{P}\right), \alpha_{\mathrm{S} 2}-\mathrm{CN}\left(\operatorname{comprises} \alpha_{\mathrm{S2} 2}-\mathrm{CN}\right.$ $11 \mathrm{P}+12 \mathrm{P}), \beta-\mathrm{CN}$ (comprises $\beta-\mathrm{CN} 8 \mathrm{P}+9 \mathrm{P})$, and $\kappa-\mathrm{CN}$ (comprises $\kappa-\mathrm{CN} \mathrm{G}+1 \mathrm{P}$ ).

${ }^{2}$ Analyzing variation between coagulation classes in Jersey milk.

${ }^{3}$ Analyzing variation between coagulating classes in Holstein-Friesian milk.

${ }^{*} P<0.05 ;{ }^{* *} P<0.01 ;{ }^{* * *} P<0.001$. Significance values calculated based on $F$-test.
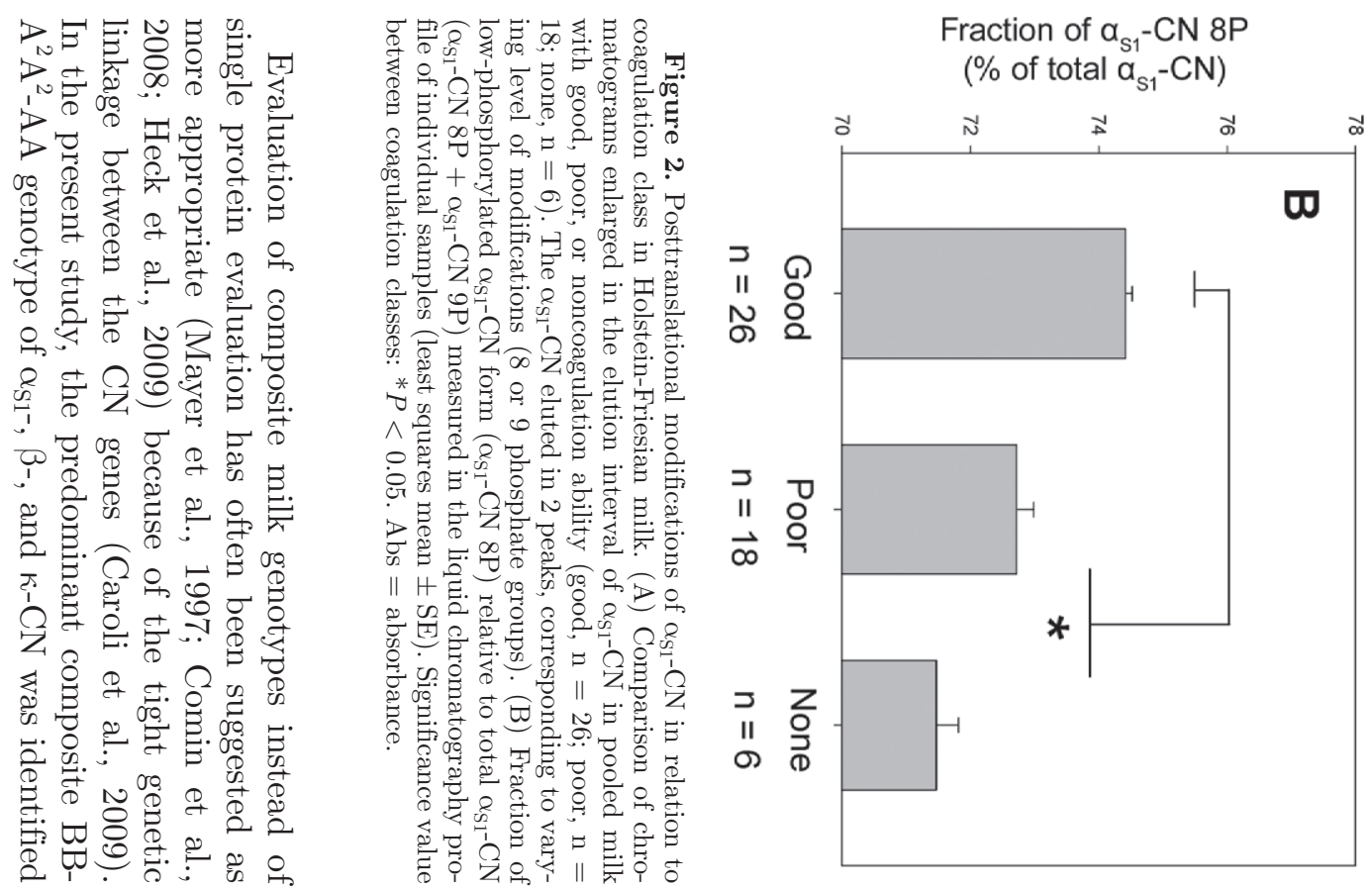

Abs $214 \mathrm{~nm}$

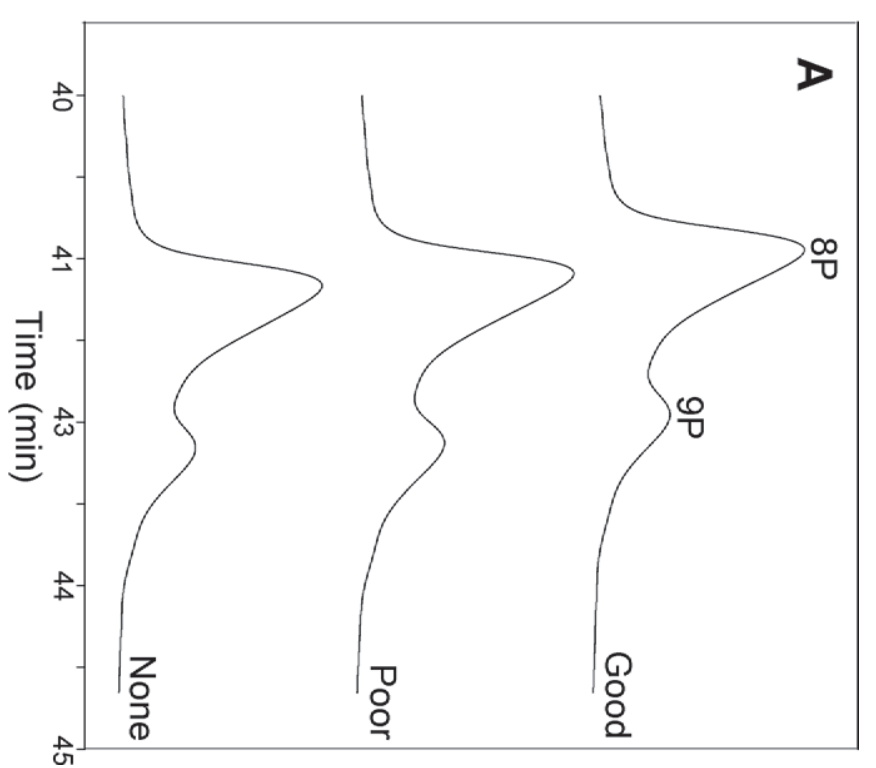



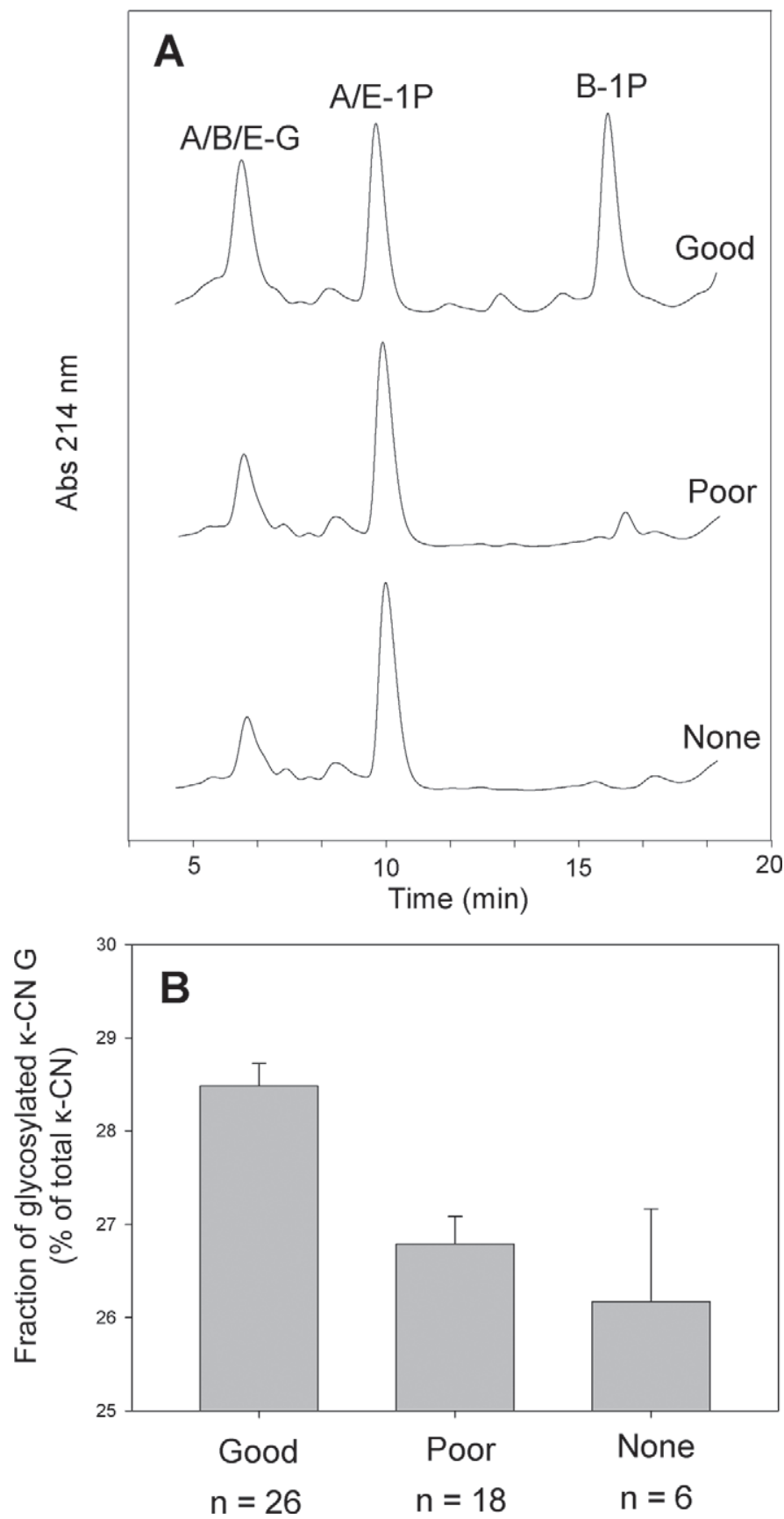

Figure 3. Posttranslational modifications of $\kappa-\mathrm{CN}$ in relation to coagulation class in Holstein-Friesian milk. (A) Comparison of chromatograms enlarged in elution interval of $\kappa-\mathrm{CN}$ in pooled milk with good, poor, or noncoagulation ability (good, $\mathrm{n}=26$; poor, $\mathrm{n}=18$; none, $\mathrm{n}=6$ ). The $\mathrm{k}$-CN eluted in 3 major peaks, corresponding to the glycosylated forms, along with unglycosylated genetic variants A, B and E. (B) Fraction of glycosylated $\kappa-\mathrm{CN}$ G relative to total $\kappa-\mathrm{CN}(\kappa-$ $\mathrm{CN} \mathrm{G}+\kappa-\mathrm{CN} \mathrm{A} / \mathrm{B} / \mathrm{E}$ ) measured in the liquid chromatography profile of individual samples (least squares mean $\pm \mathrm{SE}$ ). Abs $=$ absorbance.

in both poorly coagulating and noncoagulating milk from both breeds, confirming a genetic contribution to impaired milk coagulation ability.
In comparison with our recent gel-based study (Jensen et al., 2012), the LC-based quantification performed in the present study revealed a significantly lower content of $\kappa-\mathrm{CN}$ in poorly coagulating and noncoagulating milk in both breeds, which is in agreement with the literature (Ikonen et al., 1999; Wedholm et al., 2006; Hallén et al., 2010). This could be a consequence of the underlying $\mathrm{k}-\mathrm{CN}$ genotypes identified in this coagulation class because most results agree that the $\kappa-\mathrm{CN}$ variant $\mathrm{B}$ is related to a higher content of $\kappa-\mathrm{CN}$ than is the ${ }^{-}$-CN variant A (Ikonen et al., 1997; Di Stasio and Mariani, 2000). A lower content of $\kappa-\mathrm{CN}$ has been shown to lead to coalescence of $\mathrm{CN}$ micelles, whereas the absence of $\kappa$-CN can cause a failure of lactation because the lumina of the mammary gland can become clogged with aggregated CN (Shekar et al., 2006). Hence, the amount of available $\kappa-\mathrm{CN}$ is important for the $\mathrm{CN}$ micelle structure and stability, and $\mathrm{CN}$ micelle size has been shown to be inversely related to $\kappa$-CN content (Dalgleish, 1986; O'Connell and Fox, 2000) and to coagulation properties, with a clear relationship between larger micelles and poor coagulation properties (Frederiksen et al., 2011a).

A critical factor in CN micelle formation and stability is the presence of PTM on the CN, such as phosphorylation of all $\mathrm{CN}\left(\alpha_{\mathrm{S}^{-}}, \alpha_{\mathrm{S}^{-}}, \beta-, \kappa_{-} \mathrm{CN}\right)$ and glycosylation of $\kappa-\mathrm{CN}$, which occurs in the endoplasmic reticulum, the Golgi complex, or both (Swaisgood, 2003). Several factors determine whether a PTM will occur, including expression of the genes encoding the enzymes necessary for the modification. Tyrisevä et al. (2008) mapped chromosomal regions underlying noncoagulating milk in Finnish Ayrshires to a candidate gene, SIAT4B, a sialyltransferase catalyzing the last step of glycosylation in $\kappa$-CN. In the present study, the phosphorylation and glycosylation levels of $\mathrm{CN}$ varied to some extent between coagulation classes, whereby poorly coagulating and noncoagulating Holstein-Friesian milk contained a lower fraction of the least phosphorylated $\alpha_{\mathrm{S} 1}-\mathrm{CN}$ form, $\alpha_{\mathrm{S} 1}-\mathrm{CN} 8 \mathrm{P}$, relative total $\alpha_{\mathrm{S}_{1}} \mathrm{CN}$, in accordance with another recent LCbased study (Frederiksen et al., 2011a), along with lower fractions of glycosylated $\kappa$-CN forms relative to total $\kappa-\mathrm{CN}$. The $\kappa-\mathrm{CN} \mathrm{B}$ has been associated with a significantly higher fraction of glycosylation than has variant A (Vreeman et al., 1986; Robitaille et al., 1991; Coolbear et al., 1996), even though some results have been contradictory (Dalgleish, 1986; Lodes et al., 1996). This was not studied further in the present work but will be the focus of future studies. Little is known about the regulation and functional roles of PTM on CN in relation to technological milk properties; however, because this study showed subtle variation between coagulation classes, it may be speculated 
to be of importance in relation to rennet-induced coagulation of bovine milk.

\section{CONCLUSIONS}

The present study analyzing milk samples representing extremes in rennet-induced coagulating ability from 2 Danish breeds, Jersey and Holstein-Friesian, revealed variation in overall milk, protein, and mineral composition, along with variation in the distribution of genetic variants of the major milk proteins. For both breeds, significantly lower contents of total protein, total CN, minerals ( $\mathrm{Ca}, \mathrm{P}, \mathrm{Mg}$ ), and $\kappa-\mathrm{CN}$ were identified in poorly coagulating and noncoagulating milk compared with milk with good coagulating ability. A LC/ESI-MS screening of genetic variants of the major milk proteins in both breeds revealed that in poorly coagulating and noncoagulating milk samples of both breeds, the predominant composite genotype of $\alpha_{\mathrm{S1}^{-}}, \beta$-, and $\kappa-\mathrm{CN}$ was $\mathrm{BB}-\mathrm{A}^{2} \mathrm{~A}^{2}-\mathrm{AA}$. In addition, phosphorylation and glycosylation levels of $\mathrm{CN}$ varied, to some extent, between the coagulation classes. Poorly coagulating and noncoagulating milk contained a lower fraction of the least phosphorylated $\alpha_{\mathrm{S} 1}-\mathrm{CN}$ form, $\alpha_{\mathrm{S} 1}-\mathrm{CN} 8 \mathrm{P}$, relative to total $\alpha_{\mathrm{S}_{1}}-\mathrm{CN}$, in addition to a lower fraction of glycosylated $\kappa-\mathrm{CN}$ forms relative to total $\kappa-\mathrm{CN}$. Thus, clear differences were observed in the composition of milk, the genetic makeup of the major milk proteins, and CN PTM between milk samples with either good or impaired coagulation ability, whereas poorly coagulating and noncoagulating milk had more similar compositions.

\section{ACKNOWLEDGMENTS}

The authors acknowledge the Danish Strategic Research Council (FøSu, Copenhagen, Denmark) for financial support through the project "Milk genomics-Impact of genes for variation in milk composition and quality," which is part of the Danish-Swedish Milk Genomics Initiative. Furthermore, the authors thank Arla Foods amba (Viby J, Denmark), the Danish Cattle Federation (Skejby, Denmark), and Aarhus University (Tjele, Denmark) for financial support. The Danish sampling and analysis team of the Danish-Swedish Milk Genomics Initiative is gratefully acknowledged for excellent technical assistance.

\section{REFERENCES}

Bobe, G., D. C. Beitz, A. E. Freeman, and G. L. Lindberg. 1998. Separation and quantification of bovine milk proteins by reversedphase high-performance liquid chromatography. J. Agric. Food Chem. 46:458-463.
Bonfatti, V., L. Grigoletto, A. Cecchinato, L. Gallo, and P. Carnier. 2008. Validation of a new reversed-phase high-performance liquid chromatography method for separation and quantification of bovine milk protein genetic variants. J. Chromatogr. A 1195:101106.

Bonizzi, I., J. N. Buffoni, and M. Feligini. 2009. Quantification of bovine casein fractions by direct chromatographic analysis of milk: Approaching the application to a real production context. J. Chromatogr. A 1216:165-168.

Caroli, A. M., S. Chessa, and G. J. Erhardt. 2009. Invited review: Milk protein polymorphisms in cattle: Effect on animal breeding and human nutrition. J. Dairy Sci. 92:5335-5352.

Chaplin, B., and M. L. Green. 1980. Determination of the proportion of $\kappa$-casein hydrolyzed by rennet on coagulation of skim-milk. J. Dairy Res. 47:351-358.

Comin, A., M. Cassandro, S. Chessa, M. Ojala, R. Dal Zotto, M. De Marchi, P. Carnier, L. Gallo, G. Pagnacco, and G. Bittante. 2008. Effects of composite $\beta$ - and $\kappa$-casein genotypes on milk coagulation, quality, and yield traits in Italian Holstein cows. J. Dairy Sci. 91:4022-4027.

Coolbear, K. P., D. F. Elgar, and J. S. Ayers. 1996. Profiling of genetic variants of bovine $\kappa$-casein macropeptide by electrophoretic and chromatographic techniques. Int. Dairy J. 6:1055-1068.

Dalgleish, D. G. 1979. Proteolysis and aggregation of casein micelles treated with immobilized or soluble chymosin. J. Dairy Res. 46:653-661.

Dalgleish, D. G. 1986. Analysis by fast protein liquid chromatography of variants of $\kappa$-casein and their relevance to micellar structure and renneting. J. Dairy Res. 53:43-51.

Dalgleish, D. G. 1992. Bovine milk protein properties and the manufacturing quality of milk. Livest. Prod. Sci. 35:75-93.

Di Stasio, L., and P. Mariani. 2000. The role of protein polymorphism in the genetic improvement of milk production. Zoot. Nutr. Anim. 26:69-90.

Domon, B., and R. Aebersold. 2006. Mass spectrometry and protein analysis. Science 312:212-217.

Farrell, H. M., Jr., R. Jimenez-Flores, G. T. Bleck, E. M. Brown, J. E. Butler, L. K. Creamer, C. L. Hicks, C. M. Hollar, K. F. Ng-KwaiHang, and H. E. Swaisgood. 2004. Nomenclature of the proteins of cows' milk — Sixth revision. J. Dairy Sci. 87:1641-1674.

Feagan, J. T., L. F. Bailey, A. F. Hehir, D. M. McLean, and N. J. S. Ellis. 1972. Coagulation of milk proteins. I. Effect of genetic variants of milk proteins on rennet coagulation and heat stability of normal milk. Aust. J. Dairy Technol. 27:129-134.

Fox, P. F. 2009. Milk: An overview. Pages 1-54 in Milk Proteins-From Expression to Food. A. Thompson, M. Boland, and H. Singh, ed. Elsevier Inc., Burlington, MA.

Frederiksen, P. D., K. K. Andersen, M. Hammersh øj, H. D. Poulsen, J. Sørensen, M. Bakman, K. B. Qvist, and L. B. Larsen. 2011a Composition and effect of blending on noncoagulating, poorly coagulating and well-coagulating bovine milk from individual Danish Holstein cows. J. Dairy Sci. 94:4787-4799.

Frederiksen, P. D., M. Hammershøj, M. Bakman, P. N. Andersen, J. B. Andersen, K. B. Qvist, and L. B. Larsen. 2011b. Variations in coagulation properties of cheese milk from three Danish dairy breeds as determined by a new free oscillation rheometry-based method. Dairy Sci. Technol. 91:309-321.

Gaucheron, F. 2005. The minerals of milk. Reprod. Nutr. Dev. 45:473-483.

Graml, R., J. Buchberger, H. Klostermeyer, and F. Pirchner. 1985. Pleiotropic effects of $\beta$-lactoglobulin and casein genotypes on milk composition of Simmentals and German Browns in Bavaria. Z. Tierzücht. Züchtgsbiol. 102:355-370.

Hallén, E., T. Allmere, J. Naslund, A. Andrén, and A. Lundén. 2007. Effect of genetic polymorphism of milk proteins on rheology of chymosin-induced milk gels. Int. Dairy J. 17:791-799.

Hallén, E., A. Lundén, A.-M. Tyrisevä, M. Westerlind, and A. Andrén. 2010. Composition of poorly and non-coagulating bovine milk and effect of calcium addition. J. Dairy Res. 77:398-403. 
Hallén, E., A. Wedholm, A. Andrén, and A. Lundén. 2008. Effect of $\beta$-casein, $\kappa$-casein and $\beta$-lactoglobulin genotypes on concentration of milk protein variants. J. Anim. Breed. Genet. 125:119-129.

Heck, J. M. L., A. Schennink, H. J. F. van Valenberg, H. Bovenhuis, M. H. P. V. Visker, J. A. M. van Arendonk, and A. C. M. van Hooijdonk. 2009. Effects of milk protein variants on the protein composition of bovine milk. J. Dairy Sci. 92:1192-1202.

Holt, C. 1992. Structure and stability of bovine casein micelles. Adv. Protein Chem. 43:63-151.

Horne, D. S. 1998. Casein interactions: Casting light on the black boxes, the structure in dairy products. Int. Dairy J. 8:171-177.

Ikonen, T., K. Ahlfors, R. Kempe, M. Ojala, and O. Ruottinen. 1999. Genetic parameters for the milk coagulation properties and prevalence of noncoagulating milk in Finnish dairy cows. J. Dairy Sci 82:205-214.

Ikonen, T., S. Morri, A. M. Tyrisevä, O. Ruottinen, and M. Ojala. 2004. Genetic and phenotypic correlations between milk coagulation properties, milk production traits, somatic cell count, casein content and pH of milk. J. Dairy Sci. 87:458-467.

Ikonen, T., M. Ojala, and E. L. Syvaoja. 1997. Effects of composite casein and $\beta$-lactoglobulin genotypes on renneting properties and composition of bovine milk by assuming an animal model. Agric. Food Sci. Finl. 6:283-294.

Jensen, H. B., J. W. Holland, N. A. Poulsen, and L. B. Larsen. 2012. Milk protein genetic variants and isoforms identified in bovine milk representing extremes in coagulating properties. J. Dairy Sci. 95:2891-2903.

Joudu, I., M. Henno, S. Varv, T. Kaart, O. Kart, and K. Kalamees. 2007. Milk protein genotypes and milk coagulation properties of Estonian native cattle. Agric. Food Sci. 16:222-231.

Lien, S., J. Kantanen, I. Olsaker, L.-E. Holm, E. Eythorsdottir, K. Sandberg, B. Dalsgard, and S. Adalsteinsson. 1999. Comparison of milk protein allele frequencies in Nordic cattle breeds. Anim. Genet. 30:85-91.

Lodes, A., I. Krause, J. Buchberger, J. Aumann, and H. Klostermeyer. 1996. The influence of genetic variants of milk proteins on the compositional and technological properties of milk. 1. Casein micelle size and the content of non-glycosylated $\kappa$-casein. Milchwissenschaft 51:368-373.

Lomholt, S. B., and K. B. Qvist. 1997. Relationship between rheological properties and degree of $\kappa$-casein proteolysis during renneting of milk. J. Dairy Res. 64:541-549.

Lucey, J. A. 2009. Milk protein gels. Pages 449-482 in Milk ProteinsFrom Expression to Food. A. Thompson, M. Boland, and H. Singh, ed. Elsevier Inc., Burlington, MA.

Malossini, F., S. Bovolenta, C. Poras, M. Dallla Rosa, and W. Venturea. 1996. Effect of diet and breed on milk composition and rennet coagulating properties. Ann. Zootech. 45:29-40.

Mayer, H. K., M. Ortner, E. Tschager, and W. Ginzinger. 1997. Composite milk protein phenotypes in relation to composition and cheesemaking properties of milk. Int. Dairy J. 7:305-310.

O'Connell, J. E., and P. F. Fox. 2000. The two-stage coagulation of milk proteins in the minimum of the heat coagulation time-pH profile of milk: Effect of casein micelle size. J. Dairy Sci. 83:378-386.

Okigbo, L. M., G. H. Richardson, R. J. Brown, and C. A. Ernstrom. 1985. Coagulation properties of abnormal and normal milk from individual cow quarters. J. Dairy Sci. 68:1893-1896.
Oloffs, K., H. Schulte-Coerne, K. Pabst, and H. O. Gravert. 1992. The significance of protein variants for genetic differences in cheesemaking properties of milk. Zuchtungskunde 64:20-26.

Resmini, P., I. De Noni, and G. Sala. 1995. Chemical-analytical characteristics of milk compounds associated with abnormal coagulation aspects. Latte 20:1348-1353. (in Italian)

Robitaille, G., K. F. Ng-Kwai-Hang, and H. G. Monardes. 1991. Variation in the N-acetyl neuraminic acid content of bovine $\kappa$-casein. J. Dairy Res. 58:107-114.

Sandra, S., M. Alezander, and D. G. Dalgleish. 2007. The rennet coagulation mechanism of skim milk as observed by transmission diffusing wave spectroscopy. J. Colloid Interface Sci. 308:364-373.

Shekar, P. C., S. Goel, S. D. Rani, D. P. Sarathi, J. L. Alex, S. Singh, and S. Kumar. 2006. Kappa-casein-deficient mice fail to lactate. Proc. Natl. Acad. Sci. USA 103:8000-8005.

Stuffins, C. B. 1967. The determination of phosphate and calcium in feeding stuffs. Analyst 92:107-111.

Sundekilde, U. K., P. D. Frederiksen, M. R. Clausen, L. B. Larsen, and H. C. Bertram. 2011. Relationship between the metabolite profile and technological properties of bovine milk from two dairy breeds elucidated by NMR-based metabolomics. J. Agric. Food Chem. 59:7360-7367.

Swaisgood, H. E. 2003. Chemistry of the caseins. Pages 149-202 in Advanced Dairy Chemistry. Vol. 1. P. F. Fox and P. L. H. McSweeney, ed. Kluwer Academic/Plenum Publisher, New York, NY.

Tervala, H. L., and V. Antila. 1985. Milk with anomalous renneting properties. Meijeritieteellinen Aikakauskirja 43:26-32.

Tsioulpas, A., M. J. Lewis, and A. S. Grandison. 2007. Effect of minerals on casein micelle stability of cows' milk. J. Dairy Res. 74:167-173.

Tyrisevä, A. M., K. Elo, A. Kuusipuro, V. Vilva, I. Jänönen, H. Karjalainen, T. Ikonen, and M. Ojala. 2008. Chromosomal regions underlying noncoagulation of milk in Finnish Ayrshire cows. Genetics 180:1211-1220.

Tyrisevä, A. M., T. Ikonen, and M. Ojala. 2003. Repeatability estimates for milk coagulation traits and non-coagulation of milk in Finnish Ayrshire cows. J. Dairy Res. 70:91-98.

Tyrisevä, A. M., T. Vahlsten, O. Routtinen, and M. Ojala. 2004 Noncoagulation of milk in Finnish Ayrshire and Holstein-Friesian cows and effect of herds on milk coagulation ability. J. Dairy Sci. 87:3958-3966.

van Hooydonk, A. C. M., H. G. Hagedoorn, and I. J. Boerrigter. 1986. The effect of various cations on the renneting of milk. Neth. Milk Dairy J. 40:369-390.

Vreeman, H. J., S. Visser, C. J. Slangen, and J. A. Van Riel. 1986. Characterization of bovine $\mathrm{k}$-casein fractions and the kinetics of chymosin-induced macropeptide release from carbohydrate-free and carbohydrate-containing fractions determined by high-performance gel-permeation chromatography. Biochem. J. 240:87-97.

Walstra, P. 1999. Casein sub-micelles: Do they exist? Int. Dairy J. 9:189-192.

Wedholm, A., L. B. Larsen, H. Lindmark-Mansson, A. H. Karlsson, and A. Andrén. 2006. Effect of protein composition on the cheesemaking properties of milk from individual dairy cows. J. Dairy Sci. 89:3296-3305. 